\title{
PELATIHAN PEMBUKUAN DAN MANAJEMEN KOPERASI BAGI PENGURUS KOPERASI SMPN 26 KOTA PALEMBANG
}

\author{
Agustina Heryati1), Fauzia Afriyani2) \\ 1), 2) Program Studi Manajemen Informatika Universitas Indo Global Mandiri \\ Jalan Jenderal Sudirman No. 629 Palembang Kode pos 30129 \\ Email : agustina.heryati@uigm.ac.id ${ }^{11}$, fauzia@uigm.ac.id ${ }^{2)}$
}

\begin{abstract}
ABSTRAK
Koperasi merupakan suatu badan usaha yang dibangun dengan tujuan untuk memajukan kesejahteraan anggota pada khususnya dan masyarakat pada umumnya. Pemahaman pemanfaatan penggunaan program Pelatihan Pembukuan Dan Manajemen Koperasi Bagi Pengurus Koperasi SMPN 26. Koperasi SMPN 26 adalah suatu koperasi sekolah yang anggotanya terdiri dari guru dan siswa, yang mana salah satu kegiatan nya yaitu transaksi penjualan dan pembelian barang. Koperasi SMPN 26 dalam kegiatan transaksi penjualan dan pembelian barangnya memiliki banyak kendala yaitu diantaranya kurang terinci pencatatan data transaksi, sistem persediaan barang yang kurang terkontrol, maka berdasarkan masalah yang diuraikan sebuah sistem yang didukung dengan aplikasi khusus penjualan dan pembelian barang yang terintegrasi dengan baik dan koperasi juga dapat pengentasan kemiskinan. Didalam Koperasi dapat tumbuh dan berkembang, dibutuhkan para pengelola dan sumber daya manusia yang kompeten dan terampil di bidangnya. Oleh karenanya, sumber daya manusia yang ada di dalamnya perlu dibekali pengetahuan dan keterampilan tentang perkoperasian yang memadai.
\end{abstract}

Kata kunci : Koperasi, manajemen, pembukuan

\section{PENDAHULUAN}

Menurut UU No. 25/1992, Koperasi didefinisikan sebagai: "Badan usaha yang beranggotakan orang seorang, atau Badan Hukum Koperasi, dengan melandaskan kegiatannya berdasarkan prinsipprinsip Koperasi sekaligus sebagai gerakan ekonomi rakyat yang berdasarkan azas kekeluargaan". operasi adalah badan hukum yang berdasar atas asas kekeluargaan yang semua anggotanya terdiri dari perorangan atau badan hukum dengan tujuan untuk mensejahterakan anggotanya. Moh. Hatta, mendefinisikan bahwa : "Koperasi adalah usaha bersama untuk memperbaiki nasib penghidupan ekonomi berdasarkan tolong menolong".

Koperasi juga bisa diartikan sebagai badan usaha yang mempunyai anggota yang setiap anggota memiliki tugas dan tanggung jawab masing masing dimana setiap anggota mempunyai hak suara yang sama dalam setiap keputusan yang akan diambil. Didalam Koperasi dapat tumbuh dan berkembang, dibutuhkan para pengelola dan sumber daya manusia yang kompeten dan terampil di bidangnya. Oleh karenanya, sumber daya manusia yang ada di dalamnya perlu dibekali pengetahuan dan keterampilan tentang perkoperasian yang memadai. Sumber daya manusia yang terampil juga dibutuhkan pemberian kompensasi yang sesuai kepada pengurus koperasi agar dapat meningkatkan loyalitas dalam bekerja memajukan koperasi sekolah (Heryati. 2016).

Pentingnya penyelenggaraan pendidikan dan pelatihan ditegaskan dalam kongres International Cooperative Alliance (ICA) tahun 1966 yang memutuskan bahwa "setiap organisasi koperasi wajib melaksanakan pendidikan dan pelatihan perkoperasian untuk menyebarluaskan idea koperasi maupun praktik koperasi, baik aspek perusahaannya maupun aspek demokrasinya."

Begitu pentingnya pendidikan dan pelatihan perkoperasian bagi pengembangan gerakan koperasi, setiap undang-undang perkoperasian selalu menyebutkan perlunya menyisihkan selisih hasil usaha koperasi berupa dana pendidikan untuk pelaksanaan pendidikan dan pelatihan perkoperasian. Bahkan dalam Undang-Undang Nomor 17 tahun 2012 tentang Perkoperasian pasal 6 ayat (e) mencantumkan salah satu prinsip koperasi yaitu: "koperasi menyelenggarakan pendidikan dan pelatihan bagi anggota, pengawas, pengurus, dan karyawannya, serta memberikan informasi kepada masyarakat tentang jati diri, kegiatan, dan kemanfaatan koperasi." Menurut UU No. 17 Tahun 2012 tentang perekonomian yang dimaksaud dengan Pelatihan ini diharapkan dapat memberikan banyak manfaat bagi pengurus 
koperasi SMPN 26, selain sebagai sarana penambah pengetahuan dan keterampilan, diharapkan juga sebagai alat saring bagi pengurus Koperasi SMPN 26.

\subsection{Tujuan Penelitian}

Tujuan dari kegiatan pengabdian kepada masyarakat ini adalah

1. Meningkatkan Pengetahuan Pengurus Koperasi SMPN 26 dalam mengelola Koperasi sesuai dengan praktek Bisnis yang sehat dan dapat menjalankan usaha kopersi dengan baik.

2. Meningkatkan Kemampuan Pengurus Koperasi SMPN 26 dalam mengerjakan Administrasi dengan tertib dan benar.

3. Meningkatkan Ketrampilan Pengurus Koperasi SMPN 26 di Bidang Akuntansi Koperasi sehingga dapat mengerjakan administrasi keuangan sesuai dengan sistem akuntansi koperasi.

4. Pengurus dapat membuat laporan pertanggung jawaban setiap tahunnya sehingga RAT dapat dilaksanakan tepat waktu

\subsection{Manfaat Penelitian}

Adapun manfaat yang akan di diperoleh Pengurus Koperasi adalah

1. Meningkatkan kemampuan mengelola pembukuan bagi pengurus koperasi SMPN 26

2. Meningkatkan kemampuan mengelola manajemen koperasi bagi pengurus SMPN 26

3. Mengurangi tidak terinci pencatatan data transaksi, sistem persediaan barang yang kurang terkontrol.

4. Menambah wawasan pengurus koperasi SMPN 26 dalam penguasaan pembukuan dan manajemen koperasi.

5. Agar para peserta mengatahui fungsi dan manfaat manajemen dalam pengelolaan koperasi.

6. Dapat membuat pembukuan koperasi yang benar.

7. Dapat menerapkan fungsi-fungsi manajemen dalam kegiatan pengelolaan koperasi.

\section{METODE PELAKSANAAN PENGABDIAN}

\subsection{Tahapan Penelitian}

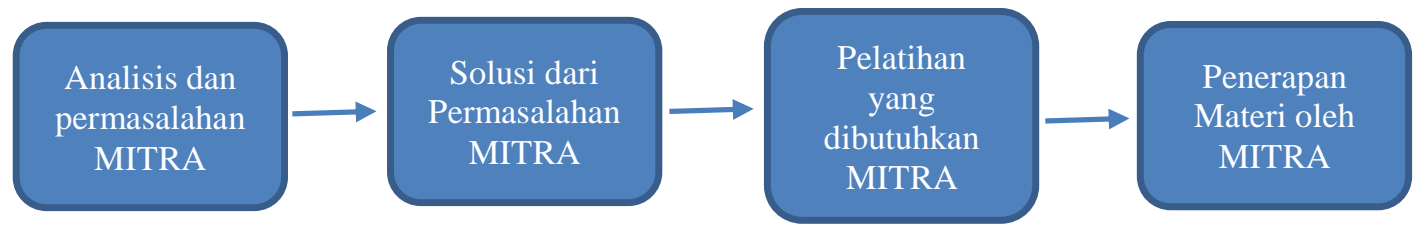

Gambar 1. Tahapan Penelitian

\subsection{Analisa dan Solusi Permasalahan Mitra}

Analisa permasalahan Mitra dapat dilakukan dengan mencari solusi yang ditawarkan adalah mengusulkan pelatihan kepada pengurus koperasi SMPN 26 untuk pengembangan penguasaan dan menambah pengetahuan dalam pembukuan dan manajemen koperasi sekolah. Dalam hal ini pengurusan koperasi juga dihadapi kelemahan-kelemahan yang sama. masalah yang menjadi penghambat berkembangnya koperasi dari sisi pengurus adalah Pengetahuan, ketrampilan, dan kemampuan anggota pengurusnya masih belum memadai, Pengurus belum mampu melaksanakan tugas mereka dengan semestinya, Masih ada koperasi yang anggota pengurusnya kurang berusaha untuk meningkatkan pengetahuan dan ketrampilannya. Pengurus kurang berdedikasi terhadap kelangsungan hidup koperasi. Ini berarti bahwa kepribadian dan mental pengurus, pengawas, manajer belum berjiwa koperasi sehingga harus diperbaiki lagi, Pengurus kadang-kadang tidak jujur, Masih ada koperasi yang anggota pengurusnya kurang berusaha untuk menigkatkan pengetahuan dan ketrampilannya. Kursus-kursus yang diselenggarakan untuk pengurus koperasi sering tidak mereka hadiri, Dalam kepengurusan koperasi sampai saat ini masih belum ada pembagian tugas yang jelas, Pengurus koperasi kebanyakan yang sudah lanjut usia dan para tokoh masyarakat yang sudah memiliki jabatan ditempat lain, sehingga perhatiannya terhadap koperasi berkurang, Pegurus masih belum mampu berkoordinasi dengan anggota, manajer, pengawas, dan instansi pemerintah dengan baik 
Pengurus koperasi juga belum tertib dalam manajemen koperasinya sehingga pelatihan ini sangat memberi manfaat bagi pengurus koperasi.

Pelatihan pembukuan dan manajemen koperasi dapat menambah keahlian, keterampilan guna kelancaran dari koperasi sekolah itu sendiri. Koperasi sekolah yang maju dapat mensejahterakan semua yang ada dilingkungan sekolah SMPN 26, yaitu guru dan siswa nya. Dengan pembukuan dan manajemen koperasi yang benar dan tertib agar tujuan koperasi tercapai dengan efisien dan efektif.

Selain itu, pengurus koperasi SMPN 26 dapat mengembangkan pelatihan pembukuan dan manajemen koperasi untuk menambah peluang bisnis yang sehat dan juga dapat mensejahterakan masyarakat. Pelatihan pembukuan dan manajemen koperasidapat memberikan wawasan dan pengetahuan bagi pengurus dan anggota koperasi tentang fungsi manajemen dan pembukuan koperasi yang benar. Adanya sosialisasi kepada masyarakat sehingga pengetahuan masyarakat tentang koperasi akan bertambah. Masyarakat dapat mengetahui bahwa sebenarnya koperasi merupakan ekonomi rakyat yang dapat menyejahterakan anggotanya. Sehingga mereka berminat untuk bergabung dengan koperasi tersebut

\subsection{Kesepakatan dengan Pihak Sekolah}

Kegiatan selanjutnya adalah membuat kesepakatan dengan pihak sekolah mengenai waktu dan tempat yang tepat untuk melaksanakan kegiatan tersebut. Pihak sekolah memberi informasi kepada seluruh pengurus kopersi, guru yang akan mengikuti pelatihan pembukuan dan manajemen koperasi tersebut.

Kapasitas Peserta pelatihan maksimal 50 orang yang terdiri guru dan pengurus koperasi sekolah SMPN 26, Kegiatan tersebut dilaksanakan selama 3 hari, dari tangal 16 Februari sampai dengan 18 Februari 2017. Pada kegiatan ini yang menjadi pelaksana adalah SMAN 26 dan Pengurus Koperasi SMPN 26 (selaku mitra).

\subsection{Persiapan Pelaksanaan}

Sebelum kegiatan pengabdian pada masyarakat dilakukan perlu adanya persiapan yang harus dilakukan terlebih dahulu yaitu:

1. Melakukan konsultasi dengan Kepala Sekolah SMPN 26 untuk memberikan pemahaman akan manfaatnya pembukuan dan manajemen koperasi bagi produktivitas pengurus koperasi.

2. Menetapkan hari, tanggal kegiatan, tempat serta peralatan yang perlu dipersiapkan untuk pelaksanaan kegiatan pelatihan tersebut. Persiapan yang dilakukan untuk pelaksanaan kegiatan tersebut adalah menyediakan ruang pelatihan untuk kapasitas 50 orang yang terdiri guru dan pengurus koperasi SMPN 26 dan kelengkapan lainnya seperti infocus, printer, spaker aktif dll. Kegiatan pengabdian dilakukan di Aula Pertemuan SMPN 26 diwajibkan bagi Dosen untuk membawa laptop masing-masing.

3. Mengajukan proposal kepada Ketua LP2MKPB Universitas Indo Global Mandiri untuk melaksanakan kegiatan pengabdian pada masyarakat.

4. Mempersiapkan materi pelatihan dalam bentuk modul yang akan dibagikan kepada para pengurus koperasi peserta pelatihan.

5. Setelah persiapan selesai, ditetapkan waktu kegiatan pada tanggal 8 dan 9 Mei 2017 di SMPN 26.

\subsection{Pelaksanaan Pengabdian}

Pelaksanan penelitian dimulai dari Pelatihan Pembukuan untuk para pengurus koperasi dan guru, persiapan laporan, materi yang akan disampaikan akuntansi pembukuan dan materi manajemen koperasi untuk para pengurus koperasi SMPN 26. Pelaksanaan didahulukan dengan penyampaian sambutan dari kepala sekolah selaku pihak penyelenggara dilanjutkan pembahasan materi untuk pengurus koperasi ada 2 (dua) materi pembahasan yakni materi pembukuan dan materi manajemen koperasi dan diakhiri dengan penutup.

Materi yang pertama adalah Pembukuan dengan menggunakan Program Akuntansi yang ada dapat juga menggunakan excel. Materi yang diajarkan tentang pengenalan dasar membuat pembukuan yang benar dan urut, selanjutnya diadakan studi kasus pembukuan yang berhubungan dengan koperasi SMPN 26.

Materi kedua adalah Manajemen Koperasi. Aplikasi yang digunakan adalah penyampaian materi dengan menggunakan ms. Power Point mengenai bagaimana teknik agar manajemen koperasi bisa tertib dan rapi juga strategi yang dapat meningkatkan manajemen koperasi bagi pengurus koperasi 
SMPN 26 agar dapat tercapainya tujuan dari manajemen koperasi sekolah tersebut.

Tabel 1. Pelaksanaan Pengabdian

\begin{tabular}{|c|c|l|}
\hline $\begin{array}{c}\text { Pertemuan } \\
\text { ke_ }\end{array}$ & Waktu & \multicolumn{1}{c|}{ Materi } \\
\hline 1 & $08: 30-12: 30$ & $\begin{array}{l}\text { Sambutan kepala sekolah smpn 26 dilanjutkan } \\
\text { Pengenalan Pembukuan }\end{array}$ \\
\hline 2 & $08: 00-12: 30$ & Pelatihan Manajemen Koperasi dan penutup \\
\hline
\end{tabular}

\section{HASIL DAN PEMBAHASAN}

Pemahaman pemanfaatan penggunaan program Pelatihan Pembukuan Dan Manajemen Koperasi Bagi Pengurus Koperasi SMPN 26, dapat meningkatkan pemahaman peningkatan produktivitas kinerja dengan memanfaatkan Teknologi Informasi. Kemampuan Pelatihan Pembukuan Dan Manajemen Koperasi Bagi Pengurus Koperasi SMPN 26 untuk berbagai keperluan dapat dipergunakan oleh karyawan untuk keperluan diluar dari kepentingan karir. Dengan pengetahuan dasar penggunaan program Microsoft powerpoint yang baik, diharapkan para pengurus koperasi di SMPN 26 lebih kreatif dan mahir membuat pembukuan.

Pembukuan koperasi bertujuan memajukan kesejahteraan ekonomi anggota pada khususnya dan kesejahteraan masyarakat pada umumnya. Meningkatkan kesejahteraan anggota adalah menjadi program utama koperasi melalui pelayanan usaha. Jadi, pelayanan anggota merupakan prioritas utama koperasi dibandingkan dengan masyarakat umum. Sistem pembukuan adalah bagian dari sistem akuntansi yang khusus menangani pencatatan transaksi dan kejadian ekonomi yang dipersiapkan untuk penyusunan laporan keuangan. Hasil dari kegiatan ini menunjukkan adanya peningkatan pemahaman pengurus koperasi dalam membuat pembukuan yang benar dan terurut.

Untuk Meningkatkan kemampuan pengurus koperasi dalam mewujudkan tujuan dari koperasi yaitu mensejahterakan pengurus koperasi di SMPN 26. Yaitu dengan mengelola manajemen koperasi. Manajemen Koperasi yang tertib dan rapi dilaksanan melalui perencanaan, organising, penggerakan untuk bekerja (actuating), dan pengawasan.

Semua kegiatan koperasi bisa dijalankan dengan baik dan setiap anggota mau mengambil bagian di dalam kegiatan koperasi serta perhatian pemerintah dapat memberikan motifasi yang baik, koperasi pasti dapat berjalan dengan lancar. Perlu dukungan dari banyak pihak untuk lebih mengembangkan koperasi. Karena koperasi akan berkembang jika dari anggotanya dapat bergerak untuk mengaktifkan usaha koperasi maka perlu penumbuhan kesadaran dan pentingnya peran anggota dalam kemajuan koperasi.

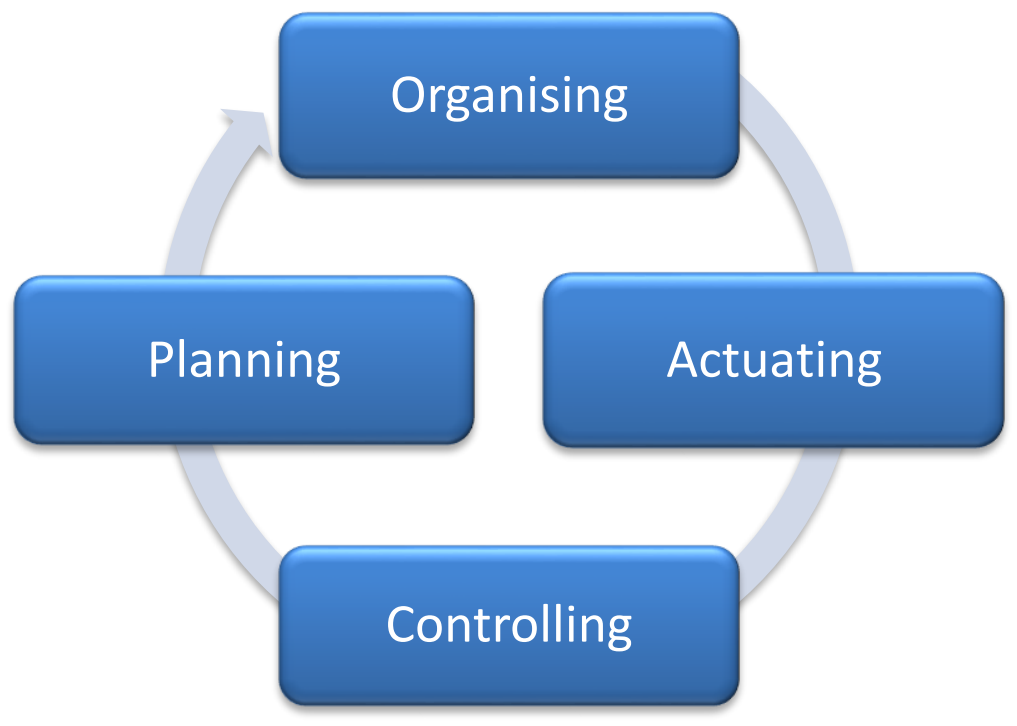

Gambar 2. Manajemen Koperasi 

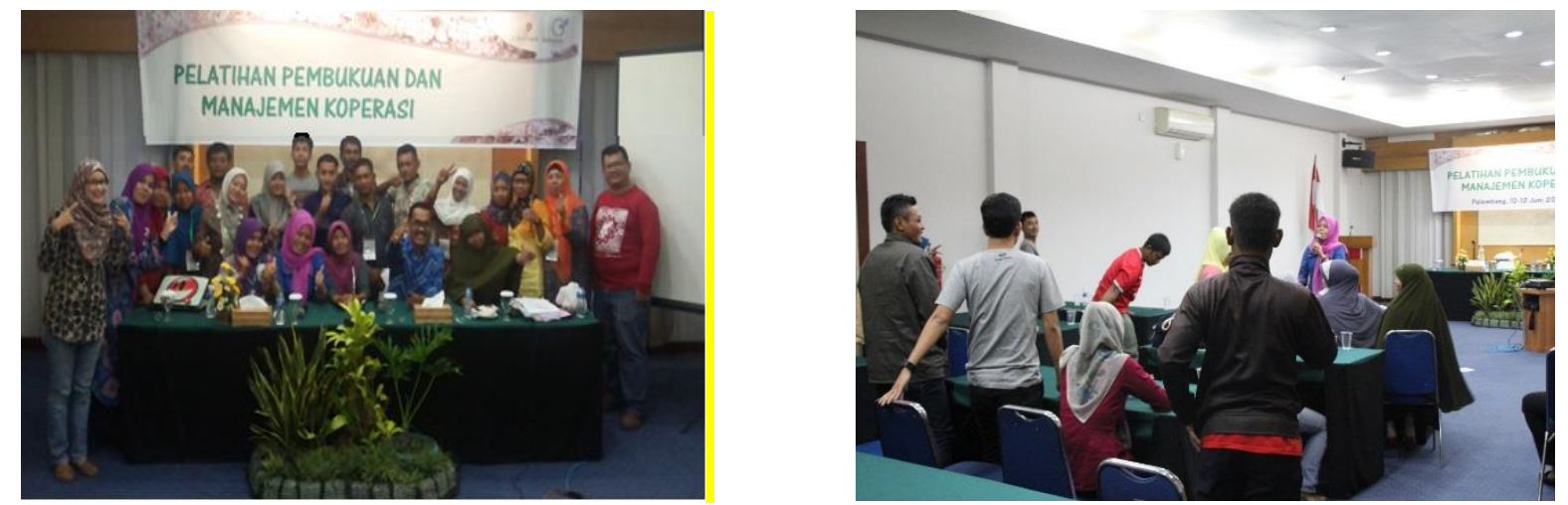

Gambar 3. Suasana Pelatihan

\section{KESIMPULAN}

Dari kegiatan pengabdian kepada Masyarakat yang telah dilakukan, maka dapat disimpulkan beberapa hal, yaitu

1. Pembukuan dan manajemen koperasi harus dilakukan secara benar sehingga dapat mewujudkan tujuan dari koperasi yaitu mensejaterakan pengurus koperasi di SMPN 26.

2. Hasil dari kegiatan pengabdian ini tidak hanya meningkatkan kemampuan para pengurus koperasi dalam membuat pembukuan dan manajemen koperasi tetapi dapat diterapkan juga dibidang lainnya seperti pembuatan bahan ajar akuntansi untuk siswa di SMPN 26.

3. Kegiatan terlaksana sesuai dengan tujuan dan rencana.

4. Kegiatan ini mendapat sambutan yang baik dari para Pengurus koperasi di SMPN 26

5. Kegiatan ini memperluas pemahaman dalam Pelatihan Pembukuan Dan Manajemen Koperasi Bagi Pengurus Koperasi SMPN 26 untuk meningkatkan produktivitas dalam menunjang karir.

\section{UCAPAN TERIMA KASIH}

Ucapan terimakasih diberikan kepada Universitas Indo Global Mandiri selaku pelindung dalam kegiatan ini. Kepala sekolah, pengurus koperasi, Guru di SMN 26 yang menjadi peserta pada kegiatan pelatihan ini.

\section{DAFTAR PUSTAKA}

Heryati. Agustina. 2016. Pengaruh kompensasi dan disiplin kerja terhadap loyalitas karyawan di Departemen operasi pupuk Sriwidjaja Palembang. Jurnal Ilmiah Ecoment Global (1) agust: 56-75 Arifin. Sitio dan Halomoan Tamba, 2001. Koperasi: Teori dan Praktik, Penerbit Erlangga, Jakarta. Hadibroto, S. Dachnial Lubis dan Sudardjat Sukadam,1991. Dasar-dasar akuntansi, Cetakan Kedelapan. Jakarta : LP3ES

Pernyataan Standar Akuntansi Keuangan (PSAK) No.27 Tahun 1999 Tentang Akuntansi Perkoperasian. Undang-Undang Nomor 17 tahun 2012 tentang Perkoperasian 